Jurnal Konstruksi Hukum | ISSN: 2746-5055

Vol. 2, No. 2, Mei 2021, Hal. 332-337| Tersedia online di

https://www.ejournal.warmadewa.ac.id/index.php/jukonhum

DOI: https://doi.org/10.22225/jkh.2.2.3232.332-337

\title{
PERLINDUNGAN HUKUM TERHADAP ANAK SEBAGAI KORBAN EKSPLOITASI SEKSUAL KOMERSIAL DI MEDIA SOSIAL
}

\author{
Putu Cyntia Rizdyanti, Anak Agung Sagung Laksmi Dewi, I Made Minggu Widyantara \\ Fakultas Hukum, Universitas Warmadewa, Denpasar - Bali, Indonesia \\ cyntiarizlS@gmail.com, laksmidewi29@gmail.com, mademinggu21@gmail.com
}

\begin{abstract}
Abstrak
Warga Negara Indonesia merupakan bagian dari unsur masyarakat dunia yang memiliki sebuah tanggungjawab besar untuk menjaga dan melindungi hak anak yang termuat dalam hak asasi manusia dimana menjadi peran utama dalam menjaga kesejahteraan anak pada kehidupan bersmasyarakat . Namun saat ini eksploitasi anak menjadi permahasalan yang sering terjadi di media sosial, setiap anak berhak memperoleh sebuah bentuk perlindungan dari segala perlakuan tindak pidana eksploitasi seksual. Pemerintah turut berperan dalam melindungi segala bentuk hak-hak anak dan memberikan edukasi tentang bahaya eksploitasi seksual di media sosial. Penelitian ini menggunakan metode penulisan hukum normatif yang mengacu pada mengenai asas, norma, kaidah dari peraruran perundangan, putusan pengadilan, perjanjian serta doktrin Teknik Pengumpulan Bahan Hukum dilakukan dengan metode kepustakaan, perundang-undangan yang dihubungkan dengan tipe penelitian hukum norrnatif dengan enganalisis setiap bahan buku yang dipergunakan untuk memilih yang sesuai dengan topik dari penelitian skripsi yang mana akan di analisis dengan sistematis dan mengaitkannya dengan bahan hukum lainnya. Penelitian ini bertujuan untuk mengetahui pengaturan perlindungan hukum terhadap anak sebagai korban eksploitasi seksual komersial di media sosial serta hukuman atau tindakan jera terhadap pelaku tindak eksploitasi seksual komersiaI anak di media sosial. Hasil penelitian mengungkapkan bahwa eksploitasi seksual anak di media sosial disebutkan sebagai pelanggaran terhadap yang termuat tentang menangani mengenai bentuk perlindungan yang diberikan terhadap seorang anak sebagai korban dari perilaku eksploitasi seksual komersial di media sosial. Tindak pidana bagi pelaku eksploitasi anak dengan membayar seratus juta rupiah dengan hukuman jeruji besi selama lima tahun.
\end{abstract}

Kata Kunci : Eksploitasi Seksual Komersial Anak, Media Sosial, Perlindungan Hukum

\begin{abstract}
Indonesian citizens as a part of the elements of the world community who have a big responsibility to protect children's rights especially in human rights, which play a major role in maintaining children's welfare in social life. However, currently the exploitation of children is a problem that often occurs on social media, every child has the right to obtain a form of protection from all criminal acts of sexual exploitation. The government plays a role in protecting all forms of children's rights and providing education about the dangers of sexual exploitation on social media. This research uses the method of writing normative law which refers to the principles, norms, rules of statutory regulations, court decisions, agreements and doctrines of the technique of collecting of data carried out by the literature, legislation which is associated with the type of normative legal research by analyzing each books to select the appropriate topic of the research that is analyzed systematically and link it with other materials. This research aims to determine the legal protection arrangements for children as victims of commercial sexual exploitation on social media as well as punishment or deterrence for perpetrators of commercial sexual exploitation of children on social media. The results of the research revealed that sexual exploitation of children on social media is mentioned as a violation of what is contained in dealing with the form of protection given to a child as a victim of commercial sexual exploitation on social media. The criminal offense for child exploitation is to pay one hundred million rupiahs with five years in prison.
\end{abstract}

Keywords: Commercial Sexual Exploitation of Children, Social Media, Legal Protection

\section{PENDAHULUAN}

Secara umum semua negara memiliki tujuan untuk membentuk tatanan kehidupan baik itu lingkup yang keciI ataupun besar, agar tercipta sebuah tatanan kehidupan masyarakat yang sejahtera, aman dan terdapat kepastian hukum yang hidup dalam masyarakat (P.A.F Lamintang, 1997: 16). Setiap anak di Indonesia telah dilindungi seluruh haknya sejak dalam kandungan oleh Negara hal tersebut telah diarur oleh Undang-Undang dan pada Hak Asasi Manusia. Dengan dilindungi hak-haknya, Negara tidak bisa menjamin seratus persen bahwa anak akan tetap dalam kondisi yang baik-baik saja. 
Dunia kini semakin berkembang dan menyesuaikan diri terhadap segala bentuk perubahan yang diciptakan oleh dunia masuk ke Indonesia. Setiap Individu sangat menikmati kecanggihan teknologi, informasi yang masuk ke Indonesia. Terrnasuk juga bagaimana menggunakan sosial media yang jaringan atau aksesnya terhubung ke seluruh dunia. (Sudrajat, 2011)

Sehingga beberapa oknum memanfaatkan kecanggihan tersebut untuk mendapatkan keuntungan yang cepat. Seperti tindak pidana eksploitasi seksual terhadap anak yang disebut dengan Children Sexual Exploitation memiliki pengertian sebagai sebuah pelanggaran atas hak-hak anak yang terdiri dari tindakan kekerasan seksual yang dilakukan oleh orang dewasa dengan cara memberikan upah uang atau benda terhadap anak atau orang lain. Anak tersebut dipergunakan sebagai sebuah percobaan seksual. Eksploitasi seksual terhadap anak adalah suatu pemaksaan dan sekaligus kekerasan atas anak, yang mengarah pada perbudakan (ECPAT, 2006:4).

Anak-anak dengan tanpa sadar telah rnenjadi konsumtif terhadap penggunaan social media tanpa tahu bahwa akibat yang ditimbulkan dari penggunaan tersebut dapat mengancam dirinya sendiri dan juga masa depannya. Terlebih lagi apabila anak-anak tergiur pada imbalan yang ditawarkan oleh manusia yang tidak memiliki tanggung jawab dan rurut serta dalam menjaga perlindungan anak dan justru rnerusak anak tersebut. Buruknya lagi lepasnya perhatian yang diberikan oleh orang rua mereka yang sibuk dengan pekerjaannya sehingga rnelupakan sebuah tugas dan tanggung jawabnya menjadi orang tua yang merniliki peran rnengasuh dan menjaga anak tersebut hingga dewasa. Karena ketika anak mendapatkan masalah dari luar, maka pedoman pertama seorang anak akan lari pada keluarga dan lingkup yang paling kecil lagi adalah lari pada pelukan orang tua. Apabila orang tua lupa peran dan tugas mereka maka akan juga kehilangan sandaran mereka dan kehilangan perlindungan pertama yang harusnya mereka dapatkan.

Oknum yang tidak bertanggung jawab sudah lebih banyak bermunculan dan secara terangterangan menggunakan anak sebagai bahan mereka untuk mendapatkan sebuah pekerjaan secara cepat. Tanpa memiliki rasa iba sedikitpun tentang masa depan anak itu. Para oknum cenderung akan secara lugas melakukan tindak pidana eksploitasi untuk kepentingan pribadi mereka yang secara sadar telah melakukan jual beli pada orang lain. Eksploitasi seksual anak tidak hanya mengganggu mental dan psikis anak dari aspek biologis, psikologis dan sosialnya sehingga akan berdampak pada perkembangannya (Khairunnisa \& Apsari, 2020). Sebagai generasi muda yang akan melanjutkan setiap aspek kehidupan di masa mendatang maka diperlukan perlindungan dari segala hal yang membahayakan khususnya terkait dengan mental dan psikis (Lismaida \& Jempa, 2017).

Kasus eksploitasi seksual anak secara komersial melalui media sosial yang dimana anak sebagai objek pemeran video porno yang bertujuan mendapatkan keuntungan individual khususnya materi maka ketentuan peraturan perundang-undangan yang berlaku adalah Undang-undang Perlindungan Anak. Peraturan ditujukan secara khusus untuk memberikan perlindungan terhadap anak sebagai korban dari tindak pidana (Rizky et al., 2019). Menurut Ratna \& Wijaya (2020) Perlindungan hukum terhadap anak merupakan salah satu upaya untuk melindungi anak dengan memberikan kebebasan hak asasi anak (Fundamental Rights and Freedom of Children). Lebih lanjut, eksploitasi seksual anak menjadikan anak menjadi pelacur anak dikarenakan beberapa alasan salah satunya yaitu faktor ekonomi. Dalam hal ini tindakan yuridis diperlukan dan mewajibkan pemerintah membentuk undang-undang yang sesuai dengan Konvensi Hak Anak Internasional (Hadi, 2015). Sedangkan menurut Putri \& Sukerti (2015) merupakan kewajiban dan tanggungjawab masyarakat dalam menanggulangi kasus ini dengan cara sosialisasi ketentuan peraturan perundang-undangan yang berkaitan dengan perlindungan anak yang dieksploitasi secara ekonomi dan seksual, pelaporan dan pemberian sanksi, dan terlibatnya instansi pemerintah maupun LSM.

Maka berdasarkan uraian diatas, penelitian ini bertujuan untuk mengetahui pengaturan perlindungan hukum terhadap anak sebagai korban eksploitasi seksual komersial di media sosial serta hukuman atau tindakan jera terhadap pelaku tindak eksploitasi seksual komersiaI anak di media sosial.

\section{METODE PENELITIAN}

Penelitian ini menggunakan penelitian secara normatif yang mana mengacu pada studi kepustakaan di bidang hukum, dengan menggunakan pendekatan masalah secara konseptual dan pendekatan kasus yang terjadi dengan menggunakan bahan hukum primer yang berpedoman terhadap UU dan 
keputusan yang mengikat, bahan Hukum Sekunder yang didapatkan melalui jurnal hukum dan buku hukum serta bahan Hukum Tersier melalui kamus hukum serta ensiklopedia yang berkaitan mengenai informasi hukum. Teknik Pengumpulan bahan hukum dilakukan dengan metode kepustakaan, perundang-undangan dengan menganalisis setiap bahan buku yang dipergunakan untuk memilih yang sesuai dengan topik dari penelitian skripsi yang mana akan di analisis dengan sistematis dan mengaitkannya dengan bahan hukum lainnya.

\section{HASIL DAN PEMBAHASAN}

\section{Pengaturan Hukum Pada Anak atas Korban Eksploitasi Seksual Komersial Anak pada Sosial Media}

Untuk mencapai keadilan suatu Negara harus mernenuhi kewajibannya untuk memberikan perlindungan hukum terhadap masyarakat, termasuk didalamnya tentang perkara anak. Yang tergolong usia dini yakni anak pada umur 0 sampai 6 tahun. Dapat dikatan anak dengan umur 0-6 tahun tengah aktif mencari tahu, betajar dan mencari sebuah pengalamann. Untuk mengoptimalkan perkembangan anak maka perlu membrkn stimulasii secar berkelanjutan. (Ahmad Susanto, 2011: 111)

Anak adalah seseorang yang belum sempuma tumbuh kembangnya, yang masih perlu sebuah pengawasan dari orang tua. Anak-Anak juga merupakan batasan usia yang begitu mudah diambil alih oleh orang yang tak dikenal, anakjuga merupakan peniru handal tindakan masyarakat di sekelilingnya tan pa mengerti tahu apakah iru perbuatan yang terpuji atau tidak. Kebodohan anak itulah yang kerap memicu anak melakukan tindakan-tindakan yang tidak senonoh dan cenderung melangkah atau mengambil jalan yang salah sehingga terjerumus pada hat yang berdampak negatif atau yang berdampak menghancurkan masa depan anak.

Pada saat mulai membentuk karakter seorang anak untuk menjadi sumber daya manusia bangsa Indonesia yang memiliki kualitas, mampu menjadi seorang pemimpin dan tentunya bisa menjaga persatuan dan kesatuan bangsa, tentu dibutuhkan sebuah pengarahan secara berkelanjutan demi mempersiapkan masa depan bangsa.

Hak anak sudah terangkum dalam Undang-Undang di setiap Negara, termasuk Negara Republik Indonesia. Negara memiliki sebuah tanggung jawab yang besar untuk memberikan jaminan atas kesejahteraan anak-anak dilihat dari konstitusional dalam UU NRJ tahun 1945. Dilihat dari hierarki hukum telah ditetapkan atas berbagai bentuk hukum yang kini menjadi sebuah landasan aturan dan aruran-aruran dalam menggunakan atau menjaga kehidupan anak di Lndonesia, mulai dari bentuk hukum nasional dan bentuk hukum internasional yang termuat hak-hak anak yang dilindungi duniadan sudah diratifikasi Indonesia (Ismawati, 2013).

Perlindungan terhadap anak yang diberikan oleh seluruh masyarakat yakni tolok ukur perkembangan zaman tersebut, karenanya wajib dimaksimalkan sesuai dengan kemampuan sebuah negara. Upaya perlindungan anak yakni suatu perlakuan hukum yang terdapat akibat hukum. Maka karena itu, harus terdapat kekuatan hukum bagi suatu upaya perlindungan untuk anak. Kepastian hukum perlu diusahakan oleh negara demi kegiatan kelangsungan perlindungan anak dan mencegah pelanggaran yang dapat memberikan akibat dan berdampak negatifyang tidak diinginkan dalam kegiatan perlindungan anak.

Dunia kini menyuguhkan berbagai macam fitur yang dapat digunakan oleh banyak orang contohnya social media dan teknologi yang masuk ke indonesia tan pa pandang bulu, sehingga manusia lebih tergiur dengan apa yang dunia suguhkan tanpa rnemilah dan mernilih yang baik untuk mereka. Fitur-fitur yang dunia suguhkan akan mempengaruhi bagaimana anak-anak berperilaku dan membuat para orang-orang yang menggunakan social media lain akan tergiur dengan apa yang anaknak itu suguhkan di media social. Sehingga permintaan untuk melakukan eksploitasi seksual oleh oknum lain semakin bertambah dan keuntungan akan bertambah. Maka dari itu oknum yang tidak bertanggung jawab akan semakin gencar mencari anak-anak sebagai korban selanjutnya.

Anak-anak dengan tanpa sadar telah menjadi konsumtif terhadap penggunaan social media tanpa tahu bahwa akibat yang ditimbulkan dari penggunaan tersebut dapat mengancam dirinya sendiri dan juga masa depannya. Terlebih lagi apabila anak-anak tergiur pada imbalan yang ditawarkan oleh manusia yang tidak merniliki tanggung jawab dan turut serta dalam menjaga perlindungan anak dan justru merusak anak tersebut. 


\section{Perlindungan Hukum Terhadap Anak Sebagai Korban Eksploitasi Seksual Komersial Anak di Media Sosial}

Perlindungan hukum mengenai anak adalah sebuah bentuk adanya hidup yang adil dan berkembang dalam suatu masyarakat dirnana semua hak tentang anak sama rata dirasakan dalam kehidupan. Adanya perlindungan hak anak dapat memberikan dampak hukum, di man a sebuah perlindungan anak yang berlaku di setiap Negara khususnya di Indonesia akan memberikan kehidupan yang layak bagi anak anak untuk penyokong kehidupan yang lebih baik.

Eksploitasi seksual komersial anak sekarang ini menjadi permasalahan yang cukup serius dan berbahaya bagi masa depan di Indonesia. Seorang anak yang masih berada pada fase bermain dengan teman seusianya justru malah dilibatkan pada kondisi dirnana hak bermain anak tersebut direnggut oleh beberapa oknum demi memperoleh sebuah keuntungan pribadi. Beberapa dari mereka justru terjun langsung bekerja dan tak jarang menjadi tulang punggung keluarga untuk dapat bertahan hidup.

Melakukan tindak pidana eksploitasi seksual baik yang masih kecil maupun perempuan merupakan kasus yang marah aktifterjadi. Dimana anak dan perempuan menjadi korban atas perlakuan manusia yang tidak bertanggung jawab. Tak hanya itu, dengan adanya perkembangan dunia yang begitu pesat menyebabkan terjadinya perubahan dalam bidang teknologi dan informasi dimana seluruh dunia siap atau tidak harus beradaptasi. Begitu pula dengan kasus eksploitasi seksual komersial anak yang kini beralih pada media sosial. Contoh kecil yang dapat dilihat adalah penggunaan internet dan teknologi, tak jarang kita melihat manusia yang sedang berkumpul asik dengan teknologi mereka masing-masing. Informasi Pun menyebar dengan sangat mudah pada media sosial dengan hanya sekali mengklik kata "share" seluruh dunia dapat mengetahui apapun yang bagikan pada media sosial.

Penggunaan media sosial inilah yang terkadang disalahgunakan oleh anak- anak diluar pengawasan orang tua. Ditambah lagi kalau anak dengan mudah menyamai apa yang telah mereka perhatikan di media sosial. Bahkan kini anak-anak yang belum mengenal baca tulis sudah mahir dengan teknologi dan media sosial.

Dari isi UU tersebut dapat dilihat jikalau perlindungan dari anak dimulai dari ruang lingkup yang kecil yaitu keluarga dimana peran seorang orang tua, keluarga dan ruang lingkup yang lebih besar lagi terdapat pada masyarakat yang harus turut andil dalam menjaga, terlindungi dan mengurus sebuah hak asasi manusia tersebut sesuai dengan tanggung jawab yang telah amanatkan oleh hukum dan Negara Republik Indonesia. Sehingga daJam sebuah perlindungan untuk anak pemerintah harus turut juga menyediakan sarana dan prasarana dalam menunjang tumbuh dan kembang anak secara menyeluruh.

Contoh kecil yang menjadi sebuah perkara yaitu bagaimana anak-anak dengan lugas bersikap pada social media yang tidak tau bagaimana dampak yang dapat ditimbulkan dari cara mereka dan perilaku yang mereka tunjukkan di media sociaJ. Anak-anak cenderung akan lari pada social media ketika perasaan mereka sedang hancur atau keadaan mereka ada pada konclisi yang paling burung. Dengan cara mengumbar hal tersebut mereka menganggap diri mereka bahwa apa yang tel ah mereka lakukan merupakan sesuatu yang benar untuk dilakukan

Sudah tidak dapat dipungkiri lagi umur anak mana yang telah merniliki telepon genggam. Orang tua yang sibuk bekerja akan lebih konsumtif memberikan anak mereka secara lugas menggunakan telepon genggam dengan alasan komunikasi saat orang rua mereka tidak ada. Justru pemikiran tersebut telah salah dilakukan oleh orang tua. Pengawasan utarna memang harus diberikan oleh orang tua keluarga mereka, bagaimana cara berpikir berkata dan berperilaku mereka akan tercermin pada dunia ketika mereka keluar dari rumah.

Dapat dilihat dari itu, para oknum yang gencar mencari anak-anak untuk dijadikan mangsa mereka melakukan eksploitasi seksual akan dengan mudah didapatkan karena upah yang mereka janjikan untuk anak-anak membuat mereka tergiur dan cenderung mengikuti apa yang oknum perintahkan. Mulai dari melakukan foto bugiil, merekam bagian rubuh yang tidak seharusnya mereka publikasikan pada orang orang dan juga melayani pada om-om muda yang tengah jenuh pada rutinitas mereka. Begitulah aJur terjadi sehingga semakin berkembangnya dunia saat ini justru sangat berbahaya bagi anak-anak yang belum tahu mana hal yang harus mereka lakukan, rnereka berikan pada orang dan mana yang tidak harus mereka lakukan. 


\section{SIMPULAN DAN SARAN}

\section{Simpulan}

Pengaturan hukum tentang anak sebagai korban eksploitasi seksual komersiaI anak di media social diatur dalam UU yang secara garis besar rnemuat ketentuan tentang perlindungan khusus dari pemerintah untuk rnelindungi anak dari tindakan eksploitasi seksual atas anak yang dilakukan oleh beberapa oknum yang tidak bertanggung jawab. Terkait dengan eksploitasi seksual anak di media sosial disebutkan sebagai pelanggaran terhadap yang termuat tentang menangani mengenai bentuk perlindungan yang diberikan terhadap seorang anak sebagai korban dari perilaku eksploitasi seksual komersial di media sosial. Hukuman atau tindakan jera terhadap pelaku tindak eksploitasi seksual komersiaI anak di media sosial diatur dalam UU perlindungan anak dengan beberapa sanksi yang diberikan oleh Negara yaitu dipidana dengan hukuman jeruji besi selama (lima) tahun atau membayar hukuman sebesar (seratus juta rupiah). Dan apabila melakukan tindakan pidana rnengeksploitasi ekonomi atau seksual terhadap seorang anak untuk rnendapatkan keuntungan personal, diberikan sebuah hukuman berupa hukuman di jeruji besi paling lama (sepuluh) tahun atau akan dikenakan sebuah denda sebanyak (dua ratus juta rupiah).

\section{Saran}

a. Kepada pemerintah khususnya pada bidang hukum, sosial, kementerian bidang pemberdayaan perempuan dan anak harus mampu mensosialisasikan pentingnya perlindungan terhadap anak kepada masyarakat.

b. Kepada masyarakat khususnya dalam lingkup yang terdekat yaitu keluarga agar mampu memberikan perhatian lebih kepada anak-anak dan mengawasi anak apabila sedang bermain media sosial karena media sosial menyuguhkan berbagai jenis konten yang belum cukup umur apabila diakses oleh anak-anak dan sering kali anak-anak mudah untuk meniru apa yang mereka lihat. Peran orang tua sangat penting dalam mengawasi seluruh kegiatan anak. Selain keluarga, peran masyarakat juga penting karena lingkungan menjadi contoh kedua yang dilihat oleh anak-anak.

c. Kepada pelaku tindak pidana agar dapat menyadari perbuatannya berlawanan dengan hukum. Dan dapat menghancurkan masa depan anak• anak, yang seharusnya masih pada masa bermain justru direnggut kebahagiaannya. Dan apabila hal tersebut diJanggar maka akan dikenakan sanksi sesuai perbuatan.

\section{DAFTAR PUSTAKA}

ECPAT Indonesia, 2006, Eksploitasi Seksual Komersial Anak, Restu Printing, Bangkok.

Hadi, A. (2015). Perlindungan Hukum Terhadap Eksploitasi Anak Menurut Undang-Undang Nomor 23 Tahun 2002. Jurnal Ummul Qura, 5(1), 72-84.

Ismawati, S. (2013). Mekanisme Penyelesaian Perkara Anak yang Berhadapan dengan Hukum pada Masyarakat Dayak Kanayatn (Kajian Perbandingan Terhadap Sistem Peradilan Anak). Jurnal Dinamika Hukum, 13(2), 197-209.

Khairunnisa, M. F., \& Apsari, N. C. (2020). Sistem Dukungan Sosial Bagi Korban Eksploitasi Seksual Komersial Anak (Eska). Social Work Journal, 10(2).

Lismaida, \& Jempa, I. K. (2017). Tindak Pidana Melakukan Eksploitasi Anak Secara Ekonomi Sebagai Pengemis (Suatu Penelitian Di Kota Banda Aceh). Junal Ilmiah Mahasiswa Bidang Hukum Pidana, 1(1), 73-84.

Putri, I. A. K. K., \& Sukerti, N. N. (2015). Perlindungan Hukum Terhadap Anak Korban Eksploitasi Seksual dalam Perspektif Undang-Undang No. 23 Tahun 2002 Tentang Perlindungan Anak. Jurnal Kertha Wicara, 4(3), 1-5.

P A.F Larnintang, 1997, Dasar-Dasar Hukum Pidana Indonesia, Citra Aditya Bakti, Bandung.

Ratna, V., \& Wijaya, M. (2020). Tinjauan Yuridis Mengenai Pemberian Perlindungan Hukum Terhadap Anak Korban Eksploitasi Seksual (Kajian Daerah Surabaya Semarang Yogyakarta). Jurnal Hukum Pidana Dan Pembangunan Hukum, 2(2). 
Rizky, M. N., Fitriani, R. I., Sudibyo, M. W., Husnasari, F. A., \& Maulana, F. (2019). Perlindungan Hukum Terhadap Anak Korban Eksploitasi Seksual Komersial Melalui Media Sosial. Jurnal Media Juris, 2(2), 197-215.

Sudrajat, T. (2011). Perlindungan Hukum Terhadap Hak Anak Sebagai Hak Asasi Manusia dalam Perspektif Sistem Hukum Keluarga di Indonesia. Kanun Jurnal Ilmu Hukum, 13(2), 111-132.

Susanto, Ahmad, 2011, Perkembangan Anak Usia Dini Pengantar Dalam Berbagai Aspeknya, Jakarta, Kencana Perdana Media Group. Hal 111. 